\title{
TAX AVOIDANCE AND THE FEDERAL ESTTATE TAX
}

\author{
Charles L. B. Lownde**
}

The seemingly unrelated provisions of the federal estate tax fall into a coherent pattern when they are approached from the point of view of purpose. There are a number of ways by which a man may obtain the advantages of a will without making a transfer which is technically testamentary. A death tax limited to the taxation of testate and intestate succession would be little more than an incentive to tax avoidance. Congress, consequently, has surrounded the primary taxes upon testamentary and intestate succession with a protective periphery of taxes upon transactions inter vivos, whose common denominator is that they might otherwise be availed of to avoid the tax. Paradoxically, perhaps, it is the taxation of these living transfers which raises the most perplexing problems under a death tax.

The most effective way to prevent avoidance of a death tax is to tax all the transfers which a person makes at the same rates and in the same fashion, regardless of whether or not they are testamentary. This rather drastic procedure, which may. suggest to some the impatient soul whe cut off his head to cure a headache, is that urged by the advocates of integration of the federal estate and gift taxes. ${ }^{2}$ So far, however, Congress has preferred to proceed along less radical lines by striving to ensnare within the provisions of the estate tax only those transfers which seem directly designed to operate in lieu of testamentary disposition.

This is, of course, a technique which calls not only for a fine exercise of legislative discrimination, but for close cooperation on the part of the courts. The most skilful draftsman cannot define with precision the transfers which may be used to avoid a death tax. In many instances the legislature is powerless to do more than formulate some general standard and rely upon the courts for its effective realization. Phrases like gifts "in contemplation of death," or transfers "intended to take effect in possession or enjoyment at or after death," are pious expressions of legislative aspiration, rather than definite descriptions of particular types of dispositions.

The history of tax avoidance in connection with the federal estate tax emphasizes the inadequacy of legislative power to deal unaided with this problem and the vital role of the judiciary. Tax avoidance under the federal estate tax is largely a problem

- A.B., 1023, Georgetown University; LL.B., 1926, S.J.D., 1931, Harvard University. Member of the New York and District of Columbia Bars. Professor of Law, Duke University. Contributor to legal periodicals.

I statement of the case for integration is presented in Altman's Integration of the Estate and Gift Taxes, infre p. 331 . 
in judicial rather than legislative behavior. A hostile court may not only hamper the efforts of Congress to prevent tax avoidance by unsympathetic construction of its acts; it may frustrate Congressional plans entirely by declaring them unconstitutional. The federal estate tax presents the difficult technical problem of reconciling certain conceptiors of the law of property, developed against a different social background, with the scheme of a modern death tax. This is not in itself a task beyond the capacity of constructive legal craftsmanship. It affords, however; a convenient opportunity for a court which resents the social implications of the federal estate tax to sabotage the tax. The federal estate, gift and income taxes are more than revenue measures. To many they appear the articulate expression of an aggressive social philosophy looking toward a radical revision of the existing order and a far-reaching redistribution of economic and political power. The temptation to a court, which is out of sympathy with the estate tax, to seize upon technical legalistic difficulties in order to frustrate its effective application, is naturally great. It would be a very slight exaggeration to say that the success or failure of the judiciary in resisting this temptation has determined the success or failure of the federal estate tax in meeting the problem of tax avoidance.

A casual scrutiny of the provisions of the federal estate tax will reveal in addition to the taxes on testamentary and intestate succession, taxes upon dower and curtesy, transfers in contemplation of death, transfers taking effect upon death, revocable transfers, survivorship in joint estates, property passing under a general power of appointment, and the proceeds of life insurance. All of these taxes with the exception of the tax on dower and curtesy are designed to strike at transactions which might be substituted for a testamentary disposition. The explicit provision for taxing dower and curtesy was written into the statute to combat the legal conception that these estates originate in the marital relation, rather than any act of inheritance.

\section{Dower and Curtesy}

The first federal estate tax, which was passed in 1916 , made no explicit provision for taxing dower and curtesy. The Treasury ruled, however, that these estates were taxable as part of the gross estate of a deceased spouse, under the general provision taxing the transfer of any property owned by a decedent at his death. ${ }^{2}$ But the courts found that in most states a surviving spouse takes dower or curtesy by virtue of the consummation of an inchoate interest originating in the marital relation, rather than any act of inheritance, and held that these interests were not taxable under the $1916 \mathrm{Act}^{3}$ To remedy this situation the 1918 and subsequent acts have contained a provision explicitly taxing dower and curtesy and their statutory substitutes." Although the justification for this tax would appear obvious, it encountered a curious hostility among the lower federal courts.

U. S. Treas. Rag. 37, Art 7 (1917).

- Randolph v. Craig, 267 Fed. 993 (D. Tenn. 1920). The Treasury thereupon modified its ruling to provide that dower and curtesy were not taxable under the 1916 Act unless by state law they were subject to charges against the estate and distributable as part of it. Art. 14, Reg. 80 (1937).

'INT. Rev. CODE \$811 (b) (cf. 1918 and I921 Acts, \$402(b); 1924 and 1926 Acts, $\$ 302(b)$ ). 
Several district courts held that the tax was a direct tax and was unconstitutional because not apportioned.5 They argued that since dower or curtesy does not arise as 2 result of any testamentary transfer, the tax was a direct tax upon property, rather than an indirect tax upon its transfer. Another district court sought to scuttle the tax by construction. The federal estate tax, it declared, taxes only the transfer of decedent estates. Dower and curtesy do not pass as part of the deceased spouse's estate. When, therefore, Congress taxed dower and curtesy it did not intend to do so. This attenuated reasoning will not astound anyone acquainted with the subtleties of legal processes. These cases were reversed by the respective circuit courts of appeals and certiorari denied from those reversals by the Supreme Court. The Court of Claims has also upheld the constitutionality of the tax upon dower and curtesy.: There is little question but that the federal estate tax does tax dower and curtesy, and that this tax is constitutional. The adverse rulings of the lower courts are, however, significantly indicative of latent judicial hostility toward the estate tax which has had more serious consequences in connection with some of its other provisions.

\section{Gifts in Contemplation of Death}

The most obvious way of escaping a death tax is to wait until death is near and then to make an outright gift of one's property. To combat this type of avoidance the federal estate tax from its inception has taxed gifts in contemplation of deach." No provision in the statute presents a more baffling administrative problem.

Most of the living transfers which are taxed under the federal estate tax, like revocable trusts or joint estates, for example, carry on their face some objective carmark which makes their identification fairly positive. A gift in contemplation of death, however, lacks any distinguishing characteristic apart from the state of mind of the donor.

It is not entirely clear what this state of mind must be. In 2 leading case, 10 , the Supreme Court said that, in making the gift, "Death must be 'contemplated,' that is, the motive which induces the transfer must be of a sort which leads to testamentary disposition."11 The Court added that a gift for a purpose associated with life would not be in contemplation of death, and then, recognizing that a gift might spring

- from mixed motives, declared that the dominant motive is controlling. That is, if a person makes a disposition of his property partly because he is prompted by the thought of death and partly from a motive,associated with life, its character will be determined by his dominant motive.

"Munroe v. U. S, 10 F. (2d) 230 (D. Neb. 1925); Hibbard v. Crooks, 25 F. (2d) 896 (D. Mo. 1927).

-Waite v. U. S., 29 F. (2d) 149 (D. Mo. 1927).

'U. S. จ. Waite, 33 F. (2d) 567 (C. C. A. 8th, 1929), cert. den. 278 U. S. 608 (1930). The constitutionality of the tax upon marital estates was also upheld in Allen v. Henggelar, $32 F$. (2d) 69 (C. C.A. 8th, 1929), cert. den. 280 U. S. 594 (1930); U. S. v. Dietz, 33 F. (2d) 576 (C. C. A. 8th, 1928) and Crooks v. Loose, 36 F. (2d) 571 (C. C. A. 8th, 1929).

Nyberg v. U. S. 66 C. Cl. 153 (2928), cerr. dcn. 278 U. S. 646 (1930).

-INT. REv. CODE, 5811 (c) (Cf. I916 Act, \$202(b); 1918 and 1921 Acts, S402(c); 1924 and 1926 Acts $3302(c)$; 1932 Aat, $\$ 803(2))$.

${ }^{20}$ U. S. v. Weils, 283 U. S. 302 (1931). $\quad{ }^{22}$ Id. 22127. 
It is obvious that a man's motives are not susceptible of measurement like this. You cannot treat a state of mind like a peck of peas. In most cases it is impossible to determine what is the dominant motive for a gift. To the uncertainty inherent in the legal definition of a gift in contemplation of death, moreover, there must be added the diffculty of proof in a concrete case. Conceding for the moment a clear judicial blueprint of the precise state of mind which is necessary for a gift in contemplation of death, still in applying his blueprint to a concrete situation, there remains the insuperable difficulty of penetrating the secret recesses of a dead man's mind.

It is scarcely surprising that the government's efforts to enforce the tax on gifts in contemplation of death fared so badly12 that Congress sought some expedient to simplify the administration of the tax. A rebuttable presumption that gifts made within a certain period of the donor's death were in contemplation of death merely rearranged the burden of proof, without affording any major assistance in determining the character of the gift. Finally in 1926 Congress adopted a conclusive presumption to the effect that any transfer of property in excess of $\$ 5,000$ within two years of a decedent's death should be deemed to be in contemplation of death. ${ }^{12}$ In Heiner v. Donnan, ${ }^{14}$ however, the Supreme Court declared that this conclusive presumption was unconstitutional.

Heiner v. Donnan is an important landmark in the history of the federal estate tax. Its importance goes beyond the immediate decision of the case. The reasoning of the majority and minority opinions in Heiner v. Donnan reflects two fundamentally divergent ways of thinking about the problem of tax avoidance under the federal estate tax. The success and failure of the tax in meeting this problem in a concrete case have been iargely conditioned by which of these two views was accepted.

Mr. Justice Stone delivered the dissenting opinion in Heiner v. Donnan. He thought that the conclusive presumption was constitutional, because this was a reasonable method of preventing avoidance of the estate tax. Briefly, he argued that Congress has constitutional power to tax transfers inter vivos under the estate tax, where this is necessary to prevent frustration of the tax. In his mind, the fact that some of the transfers taxed under the conclusive presumption might not have been made in contemplation of death was decisively outweighed by the necessity of finding some effective method of enforcing the tax upon transfers in contemplation of death. Mr. Justice Stone relied upon what is commonly called the "penumbra theory," after a vivid figure of Mr. Justice Holmes. In dissenting from an earlier decision ${ }^{15}$ where the Court outlawed a Wisconsin statute declaring that gifts made within a certain time of death should be conclusively presumed to be in contemplation of death, Mr. Justice Holmes declared: "Of course, many gifts will be hit by the tax that were

${ }^{12}$ A graphic account of the government's lack of suceess appears in the dissenting opinion of Mr. Justice Stone in Heiner r. Donnan, 285 U. S. 312, 343-346 (1932).

12 1926 Act, $5302(\mathrm{c})$, deleted by 1932 Act, $5803(\mathrm{a})$.

${ }^{14} 285$ U. S. 312 (1932). See also Handy r. Delaware Trust Co, 285 U. S. 352 (1932).

${ }^{18}$ Schlesinger r. Wisconsin, 270 U. S. 230 (1920). 
made with no contemplation of death. But the law allows a penumbra to be $\mathrm{cm}$ braced that goes beyond the outline of its object in order that its object may be secured."10

Mr. Justice Sutherland delivered the majority opinion in Heiner v. Donnan. He flatly rejected the penumbra test. Congress, said Mr. Justice Sutherland, has power to impose a gifi tax as well as an estate tax. But it cannot tax some gifts which 2re not testamentary, while other gifts of this kind go free. This is the effect of a conclusive presumption that gifts made within a certain time of death are in contemplation of death. This creates an unreasonable classification, which is. so arbitrary that it violates the due process clause of the Fifth Amendment. Stripped to its essentials, Mr. Justice Sutherland's opinion lays down the bald proposition that Congress has no constitutional power to tax any but testamentary transfers under the estate tax.

Heiner $v$. Donnan effectively chilled Congressional enthusiasm for some solution of the administrative problem created by the tax on contemplation of death. It also prescribed as a part of due process the rule that Congress in secking to prevent avoidance of the estate tax was limited to the taxation of testamentary transfers under that tax. The net effect of the decision was to establish rigid judicial supervision over Congressional efforts to prevent escape from the estate tax.

The penumbra theory leaves a fair margin for legislative discretion in adopting reasonable means to prevent avoidance of the tax. Under the testamentary transfer theory Congress is limited in its choice of means for combatting tax avoidance, and its action is subjected to rigorous judicial control. Testamentary transfer, in the sense in which that term was employed in the majority opinion in Heiner v. Donnan, lacks any standard content or definite meaning. Indeed, as Mr. Justice Sutherland pointed out in upholding the tax on gifts actually. made in contemplation of death, an outright disposition inter vivos may be "testamentary," if there is the requisite mental atritude on the part of the donor. Testamentary transfer describes no objective reality. But it is far from an empty legal metaphysic. Subtly but definitely, the Court in Heiner $\%$. Donnan expressed is doubts atout the underlying sacial philosophy behind the estate tax and its fixed determination to kesp a firm hand upon its development.

\section{Transfers Taking Effect Upon Death}

This became even clearer when the Court applied the testamentary transfer test not only as a criterion of constitutionaiity but as a canon of construction. Since the first federal estate tax in 1916, a tax has been imposed upon transfers made by $a$ decedent during his life which are "intended to take effect in possession or enjoyment at or after his death." 17 The Supreme Court has never undertaken any comprehensive definition of this phrase, preferring an ad hoe approach.as each case has arisen. To the extent, however, that it has been defined by the Court, the judicial

10 Id. at 241.

${ }^{27}$ INT. REv. COOE 5811 (c) (cf. the 1916 Ac, $5202(b)$; 1918 and 1921 Acts $5402(c)$; 1924 and 1926 Aat, $5302(c) ; 1932$ Act, $5803(a))$. 
definition is in curious contradiction to the natural meaning of the words employed by Congress.

The statute, for example, does not say a word about title. ${ }^{18}$ It is phrased solely in terms of possession and enjoyment, which assuredly could scarcely have been done without conscious intention. The type of transfer which it describes most aptly is a grant with a reservation of a life estate to the donor. 19 In this situation, although title may vest immediately in the grantec, possession and enjoyment is deferred until the grantor's death. Curiously enough, however, this is one type of . transfer which the Supreme Court has held not taxable. ${ }^{20}$ Emphasis has been placed upon a shift in title, rather than possession and enjoyment. Thus, the Court said that a revocable trust could be taxed as a transfer taking effect in possession or enjoyment at death, because the lapse of the power of revocation constizuted a testamentary transfer. ${ }^{21}$ In another case, it sustained the taxation of the gift of a contingent remainder, which was contingent upon the donee surviving the donor.22 Although the contingert remainderman was also the tenant of the presedent life estate, so that the death of the grantor did not affect his possession or enjoyment, it did, as in the case of the revocable trust, affect title. Where, however, in May v. Heiner ${ }^{23}$ there was a grant of a vested remainder with a reservation of a life estate, the Court could not find any transfer taking effect in possession or enjoyment upon the death of the grantor. Although the death of the donor certainly affected the possession and enjoyment of the property, it did not affect the remainderman's title. There was, declared the Court, nothing testamentary which justified taxing this transfer.

Miay v. Heiner is a remarkable decision. It appears to lay down as a sina qua non of a testamentary transfer some change in title rather than an accession of cconomic incidents of possession and enjoyment. Strangely enough, however, shortly after the decision in May v. Heiner, the Supreme Court, in upholding a tax upon the right of survivorship in a tenancy by the entirety, ${ }^{24}$ found that testamentary transfer does not require any shift in title, but is satisfied by a transfer of incidents of enjoyment. It is very difficult to escape the conclusion that the Court in May $v$. Heiner was less interested in the legal metaphysics of testamentary transfer, than in leaving a convenient method of disposing of one's property, without incurring. liability under the estate tax.

\footnotetext{
10 Although 5811 (c) of the Code taxes urasfers "intended" to take effec upon death, the word "intended" does not seem to be significant. The test is objective rather than subjective. That is, the controlling consideration here is whether the decedent made a transfer which takes effect upon his death, rather than whether be "intended" to have the trasfer take effect upon bis death.

10 " 'Possession or enjoyment" appears to me a phrase clearly iniended to refer to the period when remainders 'fall in,' not that at which they vest." Learned Hand, J, concurring in Frew v. Bowter, 12 F. (2d) 625,627 (C. C. $\wedge$ 2d, 1926).

${ }^{20}$ Afay v. Heiner, 281 U. S. 238 (1930). Prior to the decision by the Supreme Court, the lower federal courts were divided on this issire. MrCaughn v. Girard Trust Co, 11 F. (2d) 520 (C. C. A. 3d, 1926), and Tips v. Bass, 21 F. (2d) 460 (D. Tex. 1927), held the transfer taxable; Arnold r. U. S., 62 Ce. C. 239 (1926), held it wiss not.

21 Reinecke v. Northern Trust Co., 278 U. S. 339 (1929).

22 Klein v. U. S, 283 U. S. 231 (r93I).

2828 U. S. 238 (2930).

A Tyler Y. U. S, 28I U. S. 497 (1930).
} 
If gifts with a reservation of a life interest were not taxed under the federal estate tax, it is clear that the effectiveness of the tax would be seriously impaired. Congress acted promptly to try to close the gap left by the decision in May $v$. Heiner, by explicitly imposing a tax upon such transfers. ${ }^{25}$ This amendment raised a nice constitutional problem. Heiner $v$. Donnan ${ }^{26}$ said that only testamentary transfers can be taxed under the estate tax. May $v$. Heiner ${ }^{27}$ held that a gift with a reservation of a life interest was not testamentary. A textual comparison of thest two decisions appeared to point to the conclusion that the tax on a gift with a reservation of a life interest was unconstitutional. ${ }^{28}$

A possible escape lay in the dichotomy of testamentary transfer. In dealing with the constitutionality of the tax upon survivorship in joint estates, the Court had found a testamentary transfer in an accession of economic incidents of enjoyment. The insistence upon some change in title for a testamentary transfer might be limited to construction. It was possible that the Court might find that a gift with a reservation of a life interest was sufficiently testamentary to sustain the constitutionality of a tax upon such transfers, although as a matter of construction it had not felt that such a gift was sufficiently testamentary to be taxable as a transfer taking effect upon death. 20

The principal pertinence of these considerations lies in the fact that when the question finally reached the Supreme Court, they were found not to be pertinent at all. The tax was sustained without any reference to the necessity for a testamentary transfer. ${ }^{30}$ It was sustained squarely upon the penumbra theory of Mr. Justice Holmes, which had been rejected with such emphasis in Heiner v. Donnan. ${ }^{31}$ The Court found that the tax upon transfers with a reservation of a life interest was a reasonable method of preventing avoidance of the estate tax. It was, therefore, clearly constitutional.

To properly appreciate the shift to the penumbra theory, it will be necessary to consider certain relevant judicial developments in connection with the tax upon revocable transfers. Before coming to that, however, a further word must be added in connection with the tax upon transfers taking effect upon death.

In Klein $v$. United States, ${ }^{32}$ to which brief reference has already been made, ${ }^{83}$ a decedent during his life granted property to his wife. He gave her a present life

${ }^{28}{ }_{4} 6$ Stat. 1516 (1931); 1932 Act, 5803 (a). In May v. Heiner, Mrs. May, the decedent, created 2 trust under which her husband took 2 life estate in the income during his life, then a life estate was reserved to the decedent during her life, and then there were remainders over. In the hope that the decision might have been predicated upon the reservation of the preliminary life estate to the husband, the government carried three more cases to the Supreme Court where no such estate had been interposed. Burnet v. Northern Trust Co., 283 U. S. 782 (1931); Morsman v. Burnet, 283 U. S. 783 (1931); McCormick v. Burnet, 283 U. S. 784 (1934). These cases were decided against the government on the authority of May v. Heiner, on March 2, 1931. On March 3, I931, Congress by a joint resolution, ssepra, explicitly provided for a tax in this situation. This resolution was approved and became law on the same day.

285 U.S. 312 (1932).

${ }^{23}$ Cf. however, Guaranty Trust Co. v. Blodgett, 287 U. S. 509 (1933).

10 Thus, for example, in Guaranty Trust Co. v. Blodgett, 287 U. S. 509 (1933), the Court held that a state succession tax upon a transfer with a reservation of a life estate was constitutional.

${ }^{20}$ Helvering v. Bullard, 303 U. S. 297 (1938); Hassett v. Welch, 303 U. S. 303 (1938).

${ }^{22}$ Supra note 26.

${ }^{12}{ }_{23}$ U.S. 231 (I93I).

28 Supra note 22. 
estate and a remainder in fee, which was contingent upon her surviving him. Although there was no shift in possession when the grantor predeceased the grantee, Mr. Justice Sutherland held that the gift of the remainder was a transfer taking effect in possession or enjoyment upon the death of the grantor and was taxable as part of his gross estate. "Nothing," said Mr. Justice Sutherland, "is to be gained by multiplying words in respect of the various niceties of the art of conveyancing or the law of contingent and vested remainders. It is perfectly plain that the death of the grantor was the indispensable and intended event which brought the estate into being for the grantee and effected its transmission from the dead to the living, thus satisfying the terms of the taxing act and justifying the tax imposed."34

If it is "perfectly plain" that a gift by $A$ to $B$ of a life estate with a remainder in fee to $B$, if $B$ survives $A$, is a transfer taking effect upon death, it is not equally clear that a gift of a fee to $B$ with a provision that the property shall revert to $A$, if $B$ does not outlive $A$, accomplishes the same purpose and should be taxed in the same way? For a long time it did not appear to be so to the Supreme Court. ${ }^{35}$ The only distinetion between these grants is a "nicety of the art of conveyancing." One creates a contingent estate which will vest if the grantee outlives the grantor. The other creates a vested estate which will divest if the grantee does not outlive the grantor. In substance they are identical. Oddly enough, however, despite Mr. Justice Sutherland's cavalier comment about the niceties of the art of conveyancing, when in a later case a decedent had made a gift with a provision for reverter upon the prior death of the grantee, the Supreme Court held that this was not a taxable transfer. ${ }^{36}$ It was not testamentary. These decisions have been roundly criticized and they were overruled at the present term by a divided court. remainders," declared Mr. Justice Frankfurter in overruling the St. Louis Union Trust Company cases, "is full of casuistries." Wis "Wat a blessing it is that the law of taxation is so singularly free from them!

\section{Revocable Transfers}

In 1924 Congress added a provision to the federal estate tax explicitly taxing revocable transfers. ${ }^{39}$. Although, five years later, the Supreme Court was to hold that a sevocable trust was taxable as a transfer taking effect upon death, ${ }^{40}$ there was considerable doubt upon this point in $1924^{41}$ Moreover, Congress went much further

* 283 U. S. 2t 234 .

${ }^{2 x}$ In Helvering v. St. Louis Union Trust Co., 296 U. S. 39 (1935), and Becker v. St. Louis Union Trust Co., 296 U. S. 48 (1935), the Court held that the grant of property with a provision for reverter to the grantor if the grantec predeceased the grantor was not taxable as a transfer taking effect upon death. Chief Justice Hughes and Justices Brandeis, Stone, and Cardozo dissented. These cases were recently. overruled in Helvering v. Hallock, 6o Sup. Ct.*444 (1940), Justices McReynolds and Roberts dissenting. Chief Justice Hughes concuried in the opinion of the majority on the ground that the decision was controlled by Klein v. U. S., 283 U. S. 231 (193I).

$\begin{array}{ll}\text { "Supra note } 35 . & \text { st } 50 \text { Sup. Ct. at } 450 .\end{array}$

${ }^{\circ}$ Reinecke v. Northern Trust Co., 278 U. S. 339 (1929).

"For example, is Matter of Miller, 236 N. Y. 290, 140 N. E. 701 (1923), the New York Court of Appeals held that a trust where the settlor reserved only a power of revocation and no further interest, was not tazable 25 a transfer taking effect in possession or enjoyment upon his death. 
in the explicit tax upon revocable transfers than the Court was willing to go in taxing these transactions as transfers taking effect upon death. In Reinecke $\boldsymbol{\nu}$. Northern Trust Company, 12 the Court held that a trust which could be revoled by the settlor alone was a transfer taking effect upon death. But it refused to hold that a trust where the power of revocation could only be exercised by the settlor in conjunction with a beneficiary, constituted such a transfer. The provision of the federal estate tax explicitly taxing revocable trusts, however, applies not only where the trust may be revoked by the action of the settlor alone, but also where it is revocable by the settlor in conjunction with "any other person."

If a person creates a trust during his life, reserving an unfettered power of revocaion, it is easy enough to find a testamentary transfer upon his death in the release of the power. On the other hand, a trust which can be revoled only with the consent of a beneficiary looks much more like an outright gift. It is difficult to find that anything substantial passes upon the settlor's death, which can properly be denominated a testamentary transfer.

Taking the statute at its full face value it appeared to be unconstitutional. The problem perplexed the lower federal courts. Most of them sought to avoid it by construing the statute as limited to a situation where a grantor reserved a power of revocation alone, or in conjunction with one other than a person having a substantial adverse interest. ${ }^{14}$ That is, they construed the estate tax as though it defined a revocable trust in the same terms as the income tax. This construction was admittedly somewhat difficult, because the income tax provides explicitly that a trust which can only be revoked in conjunction with a person having a substantial adverse interest, is not a revocable trust. ${ }^{45}$ It was justified, however, on the basis of a Committee Report, which declared that the deñnition of a revocable trust under the estate and income taxes was the same, 18 in order to escape the "grave constitutional doubts" which a broader construction of the estate tax would encounter.

In the years which elapsed while this question was on its way to the Supreme Court, professional opinion crystallized along the lines taken by the lower federal courts. It was generally agreed that a trust which could be revoked only with the consent of a person having a substantial adverse interest was not subject to the estate tax, either because properly construed the statute did not apply to this kind of transfer, or because if it did apply, it was unconstitutional. This opinion was fortified by the decision in Reinecke " Northern Trust Company, "17 were the Court in dealing with a trust which could be revoked only with the consent of a beneficiary had this to say: "Since the power to revoke or alter was dependent on the consent of the one entitled to the beneficial, and consequently adverse, interest, the trust, for all practical

"supra note 40.

"Supra note 39.

"Lit v. Commissioner, 72 F. (2d) 551 (C. C. A. 3rd, 1934); Commissioner v. City Bank Farmers" Trust Co., 74 F. (2d) 242 (C. C. A. 2nd, 1934); Commissioner v. Sterens, 79 F. (2d) 490 (C. C. A. 3rd, 1935). Cortra. Commissioner v. Strauss, 77 F. (2d) 401 (C: C. A. 7th, 1935).

INT. REv. CODE 5166.

"H. R. No. 179, 68th Cong, 1st Sest (1924) p. 28.

"S Supra nove 40. 
purposes, had passed as completely from any control by decedent which might inure to his own benefit as if the gift had been absolute."18 Surely, the Court could not find any testamentary transfer here.

When the question came before the Court, however, it did not even look for a testamentary transfer. In Helvering v. City Bank Farmers Trust Company, ${ }^{10}$ a decedent, during her life, created a trust which was revocable only with the consent of a beneficiary. The Court held that the trust was taxable under the provision taxing revocable trusts. The statute, declared the Court, taxes transfers which are revocable with the consent of "any other person." This is too plain and unequivocal to be construed in any other fashion than as including a trust revocable only with the consent of a person having a substantial interest, adverse to that of the settlor. Neither committee reports nor grave constitutional doubts can be allowed to vary the construction of a statute which is not in any degree ambiguous. Starting from this construction, the Court was squarely faced with the problem of constitutionality, which it met with a blunt reversion to the penumbra theory. The tax was constitutional because it was a reasonable method of preventing tax avoidance. It was 8 reasonable method of preventing tax avoidance since otherwise the settlor of a trust might choose a complacent beneficiary as the person in connection with whom he could revoke the trust, and thus escape liability for the tax.

Helvering v. City Bank Farmers Trust Company marks a definite turning point in the Supreme Court's attitude toward avoidance of the estate tax. It was, however, in the nature of a tentative step, rather than a complete conversion. The cace antedated the recent sweeping changes in the personnel of the Supreme Court. It was the decision of a conservative judge speaking for a Court which was still predominandy conservative. ${ }^{50}$ Helvering v. City Bank Farmers Truss Company was one of a group of cases decided on the same day, and a clearer indication of the temper of the Court at that time appears from the context against which the opinion in that case was rendered, than from an isolated consideration of the decision itself.

On the same day that it abandoned the testamentary transfer conception as a test of constitutionality, the Court seemed wedded to it more firmiy than ever as a criterion of construction. This was the day when the St. Louis Union Trust Company cases $^{51}$ holding that a grant of an estate with a provision for reverter upon the grantee predeceasing the grantor was not taxable, were decided. On this occasion also the Court rendered the decision in White v. Poor, ${ }^{62}$ which could searcely be deemed inimical to the cause of the tax avoider. In White v. Poor, a decedent, during her life, had created a trust giving the trustees the power to terminate the trust. Prior to her death, she had herself appointed one of the trustee., and died while still serving in that capacity. The Court held that this was not a revocable trust, taxable as part of the grantor's gross estate, upon the rather fine reasoning that although the

19278 U. S. at 346.

" 296 U. S. 70 (1935)

${ }^{80} \mathrm{Mr}$. Justice Roberts delivered the majority opinion, writing on behalf of himself, Chief Justice Hughes and Justices Brandeis, Stone, and Cardozo. justices Van Devanter, McReynolds, Sutherland and Butler dissented.

1 Supra note 35.

* 296 U. S. 98 (2935). 
decedent had power to terminate the trust at her death, she acquired this power in her capacity as trustee rather than in her capacity as settlor. ${ }^{.5}$ Congress promptly repudiated this distinction by providing explicitly for a tax in this situation. This amendment, however, is not retroactive.

\section{Joint Estates}

In connection with certain forms of co-ownership, such as joint tenancy and tenancy by the entirety, there is what is known as survivorship. Briefly, this means that when one co-owner dies his interest inures to the surviving tenants, instead of passing to his legal representatives. The legal theory behind survivorship, which has a curious history dating back to the feudal system, is that nothing passes to the surviving tenant upon the death of his cotenant. Not only does he not acquire any interest by inheritance, he acquires nothing at all. In legal contemplation the title to a joint tenancy or a tenancy by the entirety is one and indivisible. Fach tenant has the whole title. When one dies this continues in the survivor.

It is clear that accepting survivorship on its narrow legalistic basis, it would be impossible to tax it under a tax limited to transfers by will and intestacy. ${ }^{65}$ There has, consequently, been a provision in the federal estate tax since its initial enactment in I9I6, explicitly taxing survivorship. ${ }^{56}$ The mechanics of this tax require that the value of all property owned by a deceased joint tenant or tenant by the entirety be included in his gross estate, to the extent that the decedent contributed the consideration for the property. ${ }^{57}$ Thus, if a man purchased Blackacre, paying the full consideration for the property, and took title in his name and that of his wife as tenants by the entirety, upon his death, the value of the entire property would be taxed as part of his gross estate. On the other hand, if the wife had paid for the property from her separate funds, none of it would be taxable upon the husband's death.

The Supreme Court has experienced surprisingly little difficulty in fitting the tax on survivorship into the constitutional pattern of a tax on a testamentary transfer. Although there is no transfer of title upon the death of a joint tenant or a tenant by the entirety, there is an accession of economic incidents of enjoyment. This has been deemed sufficient to constitute a testamentary transfer, which will suscain the constitutionality of the tax.

An analysis of the respective rights of joint tenants and tenants by the entirety will show just how far the Court has been willing to go in this direction. If a joint tenant or a tenant by the entirety dies, not only is his share of the property taxed as

\footnotetext{
8* Another in this group of cases was Helvering จ. Helmholz, 296 U. S. 93 (1935), which held that 2 trust under which the settlor reserved a power of revocation in conjunction with all the beneficiaries was not taxable. The Court said that the power reserved by the sertlor in this situation was simply a power to do what the law would allow him to do in the absence of any reservation. The trust was, consequently, an irrevocable, rather than a revocable, trust.

ss Attorney General v. Clark, 222 Mass. 291, 110 N. E. 299 (1915).

"INr. REv. COOE S811(c) (cf. 1916 Act, \$202(c); 1918 and 1921 Acts, 5402(d); 1924 and r926 Acts, $5302(\mathrm{e}))$.

ir Sipra note 56; U. S. Theas. ReG. 80, Arts. 22 and 23 (I937).
} 
part of his gross estate, but also the share of the survivor, provided, of course, that the decedent paid the full consideration for the property. It is fairly clear that factually, if not legally, upon the death of one tenant, the survivor succeeds to the decedent's share in the property. But how does the death of one tenant affect the surviving owner's enjoyment of his own share in the property? In the case of a tenancy by the entirety there is no right of severance, that is, one tenant cannot convey or dispose of his interest in the property without the other's concurrence. Consequently, when a tenant by the entirety dies, the remaining tenant not only acquires the decedent's share in the property, but his enjoyment of his own share is enhanced, since he may freely dispose of it without the concurrence of any other person. Death of a tenant by the entirety not only effects a transfer of the deceased tenant's interest in the property, it releases certain "strings" on the survivor's interest, so that it is possible to say that there has been a testamentary transfer of the entire property. 58

The situation in connection with a joint tenancy, however, is quite distinct. Joint tenants have a power of severance. A joint renant may convey his share in the property without his cotenant's consent. About the only limitation on a joint tenant's control over his moiety is that he cannot defeat his cotenant's right of survivorship by will: He may, however, freely do so by a conveyance inter vivos. Although the death of a joint tenant results in a transfer of the decedent's moiety to the survivor, it is difficult to see that it has any substantial effect upon the share of the survivor. The Supreme Court has recently held, however, that the entire value of property held by way of a joint tenancy may be taxed to the estate of a deceased joint tenant.00 It is true that the surviving tenant acquires the power to dispose of his share of the. property by will upon the other tenant's death. The Court felt that this was a sufficient testannentary transfer to justify taxing the survivor's share in the property. It is manifest that the decision tends to check tax avoidance. It is, however, probably a more significant indication of the present attitude of the Court toward the estate tax than the expression of a serious conviction that there really is any transfer here.

\section{Powers of Appcintment.}

The common law theory of a power of appointment is that title passes to the appointee from the donor of the power, rather than the donee. For example, if $A$ devises Blackacre to $B$ for life, with a power to appoint the remainder to whomsoever he sees fit, and $B$ appoints the property to $C, C$ acquires title from $A$, not from $B$. It follows, of course, that in order to tax the appointed property as part of the donec's estate, specific legislation is necessary. This was made clear in United States $v$. Field, ${ }^{61}$ where the Supreme Court held that property passing under a general power of appointment was not taxable as part of the estate of the donee of the powver under the 1916 Act, which failed to make any special provision for the taxation of such powers. The 1918 and subsequent Acts have explicitly taxed powers of appoint-

\footnotetext{
"xylex r. U. S., 281 U. S. 497 (1930).

U. S. v. J2cobs, 306 U. S. 363 (2939).
}

rowinn r. Commissioner, 287 U. S. 224 (1932).
2255 U. S. 257 (2921). 
ment. ${ }^{02}$ The tax is, however, very limited, and its effectiveness is open to serious question.

The federal estate tax taxes only general powers of appointment. ${ }^{63}$ Moreover; $^{\text {; }}$ the non-exercise of such a power is not taxed. ${ }^{64}$ To be taxable the power must be exercised and exercised by will or by a deed in contemplation of death or intended to take effect upon death. ${ }^{65}$ Finally, the Supreme Court has held that it is not enough for a general power to be exercised in a manner prescribed by the statute, but the appointed property must actually pass under the power. In Helvering $v$. Grin$n e l l, ; 0$ the appointees under a general power of appointment renounced their rights under the will of the donee of the power, and elected to take under a limitation in their favor in default of appointment, in the will of the donor of the power. The Court held that the appointed property could not be taxed as part of the donee's gross estate, because the property had not passed under the power of appointment.

The limited scope of the tax on powers of appointment has prevented any serious challenge to its constitutionality. But although there is no doubt that the tax in its present form is constitutional; it appears to offer an opportunity for rather widespread tax avoidance. This, however, seems fairly attributable to legislative inertia, rather than to any obstructive judicial tactics.

By the creation of successive estates and powers of appointment, it is possible to avoid the imposition of an estate tax where a tax would otherwise be due. Thus for example, if $A$ leaves his property to $B$, a tax would be due upon $A^{\prime}$ 's death and another upon $B$ 's death. If, however, $A$ leaves $B$ a life estate in the property, with a power of appointing the remainder, $B$ may enjoy the property during his life and dispose of it after his death, without incurring a second tax, providing that sufficient care is used in creating the power of appointment or in its exercise. Even though the power given to $B$ was a general power, no tax liability would arise, unless the power was exercised in a manner prescribed by the statute. If the power were special, no liability would be incurred, regardless of whether or not it was exercised.

The legislative remedies here are clear. There is, however, a serious question how rigorously they should be applied. Avoidance of an estate tax by means of a power of appointment çan easily be prevented by providing for a tax upon the non-exercise as well as the exercise of a power of appointment and taxing special as well as.general powers. Such a tax might even be extended to the exercise of a power by any form of conveyance inter vivos as well as to dispositions by will, or dispositions inter vivos designed to operate in lieu of a will. There has been an interesting debate on this. subject between Professors Griswold and Leach of the Harvard Law School. ${ }^{\text {6r }}$. Professor Griswold feels that tax avoidance by means of powers of appointment is a serious evil calling for drastic legislative action. Professor Leach makes the point in

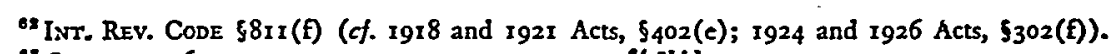

os Supra note 62 .

${ }^{\circ}{ }_{1 b i d .}{ }^{60} 294$ U. S. 153 (1935).

${ }^{\circ}$ Griswold, Powers of Appointment and the Federal Estate Tax (1939) 52 Harv. L. Rev. 929; Leach, Powers of Appointment and the Federal Estate Tax-A Dissent, id. 961; Griswold, In Reply, id.
} 967. 
reply that, if special powers of appointment are taxed, taxpayers will continue to avoid the tax by disposing of their property by creating successive estates, without any powers of appointment. This will mean that the revenue from the federal estate tax will not increase, but there will be an increase in unwise and inflexible family settlements. Professor Leach's position is that the special power of appointment is a desirable social device which should not be penalized by a tax which will result in no addition to the public revenues.

The non-exercise of a general power of appointment, as well as its exercise, should be specifically taxed. This will not interfere with wise family setdements. Failing to exercise a general power is one way of exercising it. Taxing the exercise, but not the non-exercise, of such powers creates an unwarranted discrimination between taxpayers who enjoy the same capacity for controlling the disposition of property after their death.

As long as the federal estate tax can be avoided by the creation of suicessive estates, there is real substance in the argument against taxing special powers of appointment. The point that such a tax will not substantially increase the return from the estate tax, but simply encourage unwise and inflexible dispositions of property, is one to be seriously considered. The real problem here seems to be this. There are undoubtedly powers, like the powver to appoint property among the children of the donee of the power, for example, which are not designed to avoid a tax but to intro. duce a desirable flexibility into a common form of family settement. Instead of giving property to $A$ for life with a remainder to $A$ 's children, it may be sensible and desirable to give $A$ a special pewer of appointing the remainder among the children on the basis of needs and aptitudes revealed by the future. To tax a power like this probably would not lead to abandoning the creation of successive estates but mercly to eliminating the special power of appointment. There would be little gain in revenue and a net loss from the social point of view of encouraging wise dispositions of property. On the other hand, if the term "general" power in the present statute is limited to a power to appoint to any one in the world or to a very large class, it is perfectly possible to have a powser of appointment which is not taxable and which serves no purpose except to avoid the estate tax. There is no significant difference, for example, between a power to appoint to anyone in the world, or a power to appoint to anyone except a Hottentor, or a corporation, or to appoint to any American citizen. The desirabie thing to do, obviously, is to tax powers which are designed for tax avoidance, and to exempt the powers which have a legitimate purpose in providing flexibility in the ordinary family settlement. It is possible that the Treasury can work out a definition which will achieve this result within the framework of the present statute by construing the term "general" to hit tax-avoiding powers.88 If it can formulate such a definition and make it stick in the courts, there is no need

- At the present time the Treasury defines a general power as one "to appoint to any person or persons in the discretion of the donee of the power, or, bowerer limited as to the persons or objects in whose tavor the appointment may be made, is exercisable in faror of the donce, his estate or his creditorx" U. S. Trens REc. 80, Art 24 (1937). It is rey doubiful whether this definition is ight enough to catch "zax-aroidiog powers." 
for active legislative intervention. It is also possible, however, that it will be found impossible to formulate such a definition, and that the only way to catch the taxavoiding powers is to tax all powers of appointment. ${ }^{69}$ If this proves to be true, then the question is not one solely of the desirability of taxing powers of appointment, which have a legitimate purpose and are not aimed at tax avoidance, but of whether such a tax may not be justified as the only satisfactory way of catching powers designed to escape imposition of the tax.

\section{Insurance}

Insurance offers one of the most popular methods of escaping from the estate tax at the present time. Tax avoidance has become as compelling a part of the average insurance agent's sales talk as the pathetic picture of the poor widow and orphans when the father of the family neglected to insure his life.

Insurance was not taxed explicilly under the first federal estate tax, although the Treasury ruled that policies payable to the insured's estate were taxable, just like any other property which he owned at his death. ${ }^{70}$ The 1918 Act and the subsequent statutes have provided explicitly for the taxation of insurance. ${ }^{71}$ All the insurance payable to the estate of the insured is taxed. ${ }^{72}$ As far as the statutory language is concerned insurance payable to other beneficiaries is taxed to the extent that it exceeds $\$ 40,000$.

The insurance exemption of $\$ 40,000$ is in addition to the regular estate tax exemption, and affords, of course, a perfectly legitimate statutory method of minimizing one's tax. If a man died and left $\$ 40,000$ in bonds and $\$ 40,000$ in-life insurance payable to his estate, he would have a taxable estate of $\$ 40,000$. If, however, he had made his insurance payable to his wife, there would be no taxable estate at all.

In addition to the explicit insurance exemption, however, the Courts and the Treasury between them have created a much more extensive exemption on the slim foundation of what is known as "legal incidents of ownership." This doctrine seems

" Congress might, however, attempt the milder expedient of taxing all powers with certain stated exceptions, such as a power to appoint the property among the descendants of the donor or the donee. This might catch the tax avoider, without unduly burdening powers designed merely to insure flexibility in the ordinary family settlement.

${ }^{70}$ U. S. TREAS. REG. 37, Art. 10 (1917).

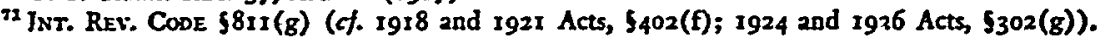

i2 As far as the statutory requirement that insurance in order to be taxable must be "taken out" by the insured is concerned, this seems to be meaningless where the insurance is payable to the decedent's estate, since the Treasury's position is that any insurance payable to the estate of the insured is "zaken out" by the insured. U. S. Treas. Reg. 80, Art. 25. The effect of this requirement where the insurance is payable to "other bencficiaries" is not clear. The Treasury for a number of years took the position that such insurance is not taken out by the insured where the beneficiary pays the premiums, and to the extent that premiums are paid by the beneficiary must be excluded from the insured's gross estate. U. S. Trens. REG. 37, Art. 32 (1918 Act); id. 63, Art. 27 (1921 Act); id. 68, Arts. 25, 28 (1924 Act); id. 70, Arts. 25, 28 (1926 Act). In Lang v. Commissioner, 304 U. S. 264 (1938), the Supreme Court held that this was 2 reasonable construction of the statute, and that not only should that part of the insurance for which the beneficiary paid the premiums be excluded from the gross estate of the insured but also any insurance for which any one other than the insured paid the premiums. The present position of the Treasury, however, is that insurance is "taken out" by the insured, regardless of who pays the premiums, if he retains any "legal incidents of ownership" in the policy. U. S. Treas. REG. 80, Art. 25 (1937). Whether this construction is proper and, if so, is constitutional, remains to be seen. 
to have originated in what may well prove to be an unwarranted inference from the case of Chase National Bank v. United States. ${ }^{73}$ In that decision, the Supreme Court held that certain insurance policies payable to beneficiaries, other than the estate of the insured, were subject to the federal estate tax, because the insured had reserved a power to change beneficiaries, and the lapse of this power upon his death constituted a testamentary transfer. The inference has been drawn from this decision both by the Treasury ${ }^{74}$ and the lower federal courts, ${ }^{75}$ that unless an insured retains something analogous to a power to change beneficiaries in a policy upon his life, this cannot be taxed as part of his gross estate. That is, in order for the policy to be taxable, the insured at his death must have some legal incident of ownership in the policy. Legal incidents of ownership in an insurance policy, according to the current regulations, include "the right of the insured or his estate to its economic benefits, the power to change the beneficiary, to surrender or cancel the policy, to assign it, to revolie the assignment, to pledge it for a loan, or to obtain from the insurer a loan against the surrender value of the policy, etc."

The consequence of the incidenis of ownership doctrine, of course, is that regardless of the amount of insurance which a man leaves, none of this is taxable as part of his estate, if he completely divests himself of any interest in the insurance during his life. The statute itself does not say a word about incidents of ownership. The only justification for this limitation upon the statutory language is that any other construction would be unconstitutional. This, however, seems highly debatable. It is not at all clear that there is not a testamentary transfer where a person insures his life in favor of a beneficiary other than his estate, and prior to his death proceeds to divest himself of any interest in the policy. Complete iegal rights to the policy may arise in the beneficiary during the insured's life. However, his enjoyment of the proceeds of the policy are certainly contingent upon the insured's death. If the insured paid for the policy, it is not difficult to visualize the situation here as a transfer of the proceeds of the policy from the insured to the beneficiary upon the insured's death, under which the insurer acts as a mere conduit for the transfer. ${ }^{77}$. A more forthright fashion of sustaining such a tax, however, appears to be afforded by the

is 278 U. S. 327 (1929).

"U. S. Trese Rra. 80, Ar. 25 (1937).

is The Court of Claims in 2 recent decision has, however, cast doubt upon the proposition that insurance cannof be taxed unless the insured setined legal incidents of ownership. In Bailey r. U. S., 27 F. Supp. 617 (Ct. Cl. 1939), it was held that insurance could be waxed despite the fact that prior to his death the insured had made 2 complete and irrerosable assignment of the policies. On a motion for 2 new trial, howerer, the court found that after the assignment the premiums were paid by the insured's wife, a beneficiary, and reversed its former cocision, holding that the insurance was noe earable Bailey $\mathbf{r}$. U. S, 30 F. Supp. 184 (Ct. Cl. 1939). After the docision in Helvering r. Halleck, 64 Sup. Cl 444 (1940), supra note 37, another motion for a nex trial was made. The court again reversed itself and held that the insurance was taxable, since upon the prior decease of the benciciaries the polivies reverted to the insured. Bailey r. U. S., (Cl. Cl, March 4, 1940) 1940 Alexasded Fed. Tax Serv, par. 2332.

76U. S. TreAs. REG. 80, ATt 25 (1937).

${ }^{73}$ See Bailey v. U. S., 27 F. Supp. 617 (C. Cl. 1939). It might be argued that Bingham v. U. S. 296 U. S. 21 : (1935), and Industrial Trust Co. v. U. S., 296 U. S. 220 (1935), beld that insurance payzble to "other beneficiaries" cannot be taxed unless at his death the insured reains "legal incidents of ownership." It is extremely doubtful, howerer, whether these cases stand for anjthing more than the proposition that the 1918 and 1926 acts will not be construed retronctively to apply to such insuranis taken out prior to the passage of the $1918 \mathrm{Aa}$. 
recent decisions which have upheld taxes upon transfers inter vivos under the estate tax, where this was reasonably necessary to prevent tax avoidance. ${ }^{78}$ There can be little doubt but that the present administration of the tax on insurance leads to very widespread avoidance of the estate tax. It is difficult to see how this can be corrected by anything short of a complete repudiation of the "legal incidents of ownership" doctrine and the application of the tax to all policies of insurance, as the statute explicitly provides. An exception might, perhaps, be legitimately made in the case of policies where the insured has not paid the premiums for the policy, either directly or indirectly. ${ }^{79}$ Indirect payment of the premiums would, however, have to be carefully guarded against to prevent tax avoidance, if this exception were made.

It is difficult to believe the present statute is not completely constitutional as it is written, and that insurance could not constitutionally be taxed as part of the gross estate of the insured, regardless of whether or not at his death he retained any incients of ownership. It is possible, however, that the administrative construction of the statute, requiring incidents of ownership as a condition of taxability, will be found to have been adopted by Congress, by repeated reenactment of the various revenue acts in the face of this construction. To avoid any ambiguity upon this point, it would probably be well to have an explicit Congressional repudiation of the incidents of ownership doctrine.

\section{Retroactive Taxation}

Congress has sought to close the avenues of escape from the federal estate tax not only by taxing various living transactions, but by taxing them retroactively. ${ }^{80}$ Although such transfers are not taxed unless there is a statute in effect at the transferor's death taxing them, they are usually taxed if there is such a statute then in. effect, despite the fact that there was no such statute in force at the time the transaction was entered into. No feature of the tax has evoked more bitter hostility nor been the subject of more unremitting attack before the courts.

No stretch of the imagination is required to picture the chagrin of a lawyer who has advised his client to make an elaborate settlement of his property during his life, in a manner which was not taxed under the contemporary provisions of the federal estate tax, and then finds himself faced with a later statute taxing these dispositions at his client's death. While to the disinterested observer Congress's effort, not only to prevent tax avoidance in the future, but to remedy its omissions in the past, may seem entirely laudable, to our hypothetical solicitor the retroactive aspects of the federal estate tax seem both lacking in sportsmanship and clearly unconstitutional. :

The courts have found this a difficult problem. As a starting point, it is clear that there is no provision in the federal constitution which explicitly forbids a retroactive tax. The prohibition against ex post facto laws is limited to criminal matters.

Usually the retrospective provisions of the federal estate tax are attacked from one or all of three angles. It has been contended, and with rather remarkable success.

${ }^{28}$ Helvering v. City Bank Farmers Trust CO, 296 U. S. 70 (1935); Helvering v. Bullard, 303 U. S. 297 (1938).

\footnotetext{
"See note 72, supra. 
that a tax which appears on its face to be retroactive must be construed as solely prospective, to avoid grave constitutional doubts. To avoid such dubiety, for example, statutes taxing transfers made "at any time" are generally construed to mean "at any time after the passage of the taxing act." ${ }^{\text {"1 }}$ Moreover, a blanket provision to the effect that the taxes upon transfers inter vivos under the federal estate tax shall apply to transfers made prior to the passage of the tax, has been construed as inapplicable where this would raise constitutional doubts, ${ }^{82}$ and to an amendment to the taxing provisions, adopted after the enactment of the blanket provision for retroactivity. ${ }^{85}$

The attacks upon the constitutionality of a tax deemed unequivocally retroactive have met with less success. There are two possible approaches here. One is to contend that a tax upon a transfer made prior to the enactment of the taxing act cannot be a $\operatorname{tax}$ upen the transfer but must be a tax upon the subject matter of the transfer. The conclusion which follows from this premise is that such a tax is a direct tax which is unconstitutional unless it is apportioned. ${ }^{84}$ The obvious answer to this argument, and one which the courts usually make, is that a transfer may be taxed just as readily by a statute passed after the transfer as by one which precedes it. That is, the fact that the transfer is taxed retroactively does not alter the fact that it is the transfer which is taxed.

A more successful objection to the constitutionality of a retroactive tax is that it is so unfair that it violates due process. At one time the Supreme Court was quite receptive to this argument so far as death taxes were concerned. The view which appeared to prevail was that a retrospective tax upon an irrevocable transfer was unconstitutional. ${ }^{85}$ This was qualified to the extent that a transfer taxable at the time it was made could be constitutionally taxed under a later statute in force at the transferor's death, since he was deemed to have had sufficient warning of the possibility of such a tax from the earlier legislation. ${ }^{88}$ On the other hand, a retroactive tax upor, a revocable transfer was constizutional. ${ }^{87}$ The philosophy behind these decisions seems to have been that the unfairness of a retroactive tax lies.in the element of surprise. It is unfair for the government to encourage (at least, passively) a person to make a transfer which is tax-free and then to turn around, after he is irrevocably committed to the transaction, and tax him upon it. If the transfer were revccable, however, then the taxpayer couid tear it up after the statute was passed and escape the tax. If he chooses to let it stand, it is not treating him unfairly to tax it.

\footnotetext{
${ }^{32}$ Shwib v. Doyle, 258 U. S. 529 (1922); Knox v. AcElligott, 258 U. S. 546 (1922); Leurllyn v. Frich, 268 U. S. 238 (1925); Bingham v. U. S., 296 U. S. 211 (1935).

"Industrial Trust Co. v. U. S, 296 U. S. 220 (2935).

sa Hassett v. Welch, 303 U. S. 303 (1938).

"Amberg, Retroactive Excise Taration (1924) 37 Hnav. L Rxv. 69x.

${ }^{65}$ Nichols r. Coc'jdge, 274 U. S. 531 (1927); Coolidge r. Long, 282 U. S. 582 . (1931): Blodgett v. Holden, 275 U. S. 142 (1928); Helvering r. Helmbolz, 296 U. S. 93 (1935); Kzite r. Poór, 296 U. S. 98 (1935). Cf. howerer; Third National Bank \& Trust Co. ४. Hhite, 287 U. S. 577 (1932).

* Milliken צ. U. S., 283 U. S. 15 (1931); Phillips v. Dime Trist se Safe Deposit Co, 284 U. S. 160 (1931); Klein v. U. S. 283 U. S. 231 (193I).

${ }^{37}$ Reirecke v. Northern Trust Co, 278 U. S. 339 (1929).
} 
It is quite possible that the Court in emphasizing fairness to an individual taxpayer in these decisions failed to stress sufficiently the competing interests of other taxpayers. Someone pays for the support of government. If one citizen escapes a tax, this cannot be written off the public ledger entirely. It must be made up from the contributions of the other members of the body politic. Granted that the retroactive taxation of transfers inter vivos may be unfair, it is quite possible that it is not as unfair as the failure to tax them retroactively would be. Suppose, for example, that $A$ and $B$ have disposed of their property during their lives by identical conveyances. They die on the same day. $A$, however, gave away his property before the passage of a statute taxing his gifts. $B$ conveyed away his property after such legislation had been enacted. It is fairer to tax these two individuals in the same way, or to exempt one and tax the other, merely because of an accident of chronology? There are competing considerations here. The question is not solely of hardship to an individual taxpayer, but of equality between taxpayers generally.

The extent to which the Supreme Court has been infuenced by these considerations is not clear. It is clear, however, that the Court is rapidly retreating from its earlier position, or what appeared to be its earlier position, to the effect that an irrevocable transfer cannot be taxed retrospectively. 88 The explicit reasoning of these later decisions, however, has taken an unhappy turn. Instead of talking about the standards of fairness and public interest embodied in due process, the.Court has approached these problems like a medieval conveyancer. Where it might have asked whether the retroactive tax was a reasonable method of preventing tax avoidance and equalizing the burden of the tax, the Court has strained to find some testamentary event after the passage of the statute, which would enable it to say that the tax was prospective, rather than retrospective. The method of reasoning has been so disingenuous and artificial that, in trying to avoid the appearance of conflict with earlier decisions, the Court has succeeded not only in undermining completely any confidence in the earlier cases but in obscuring entirely its position in the later ones.

In Coolidge v. Long, ${ }^{\text {s9 }}$ for example, the Court held that a death tax could not constitutionally be applied to a transfer with a reservation of a life estate, occurring prior to the passage of the taxing act. In Binney $\nu$. Long, ${ }^{90}$ the Court heid that a tax could constitutionally be imposed upon such a transfer effected prior to the passage of the taxing act. The transfers in both cases were irrevocable. Binney $v$. Long did not purport to overrule Coolidge $v$. Long. It distinguished it on the ground that the remainders in Coolidge $v$. Long vested prior to the passage of the taxing act, so that the tax was retroactive, while in Binney $\nu$. Long they vested after the passage of the taxing act, so that the tax was prospective. This is scarcely a sensible distinction. The question in these cases was not whether the Constitution forbids a retroactive tax. Obviousty, it does not. The question was whether the taxes were so unfair that they violated due process. The time at which the remainders vested, or whether the

sa Binney v. Long, 299 U. S. 280 (1936); U. S. v. Jacobs, 306 U. S: $3 \dot{63}$ (1939).

1" 282 U. S. 582 (r93I).

${ }^{\circ} 299$ U. S. $280(1936)$. 
transferor created vested or contingent remainders, had no bearing upon the question of fairness. In both cases the decedents had made irrevocable transfers. They were subjected to the same type of unfair surprise.

It would impugn the intelligence of the Supreme Court to think that the justices really believe that due process, or the lack of it, turns upon any distinction as whimsical as that between vested and contingent remainders. It is difficult to believe that Binney v. Long does not represent a new evaluation of the social considerations connected with retroactive taxation; that it does not entircly repudiate the decision in Coolidge v. Long. The Court's phrasing of the problem seems unhappily chosen. It can scarcely add to its stature in the eyes of the citizenry to see the justices approach problems of due process with the social outlook of a fifteenth-century solicitor. The real issues here are issues of fairness and justice, whether the retroactive tax is a reasonable method of preventing tax aroidance and achieving equality of the tax burden. It is difficult to discover any worth-while purpose which is subserved by concealing them behind a maze of metaphysical anachronisms.

\section{Conclusion}

Modern federal estate, gift and income taxes with their steep progressions and rigid emphasis upon the ability-to-pay principle are more than mere revenue measures. They have significant social implications. As a revenue measure, for example, the federal estate tax violates the elementary canons of sound taxation. It has been justly likened to the improvident husbandman who feeds upon his seed corn. The burden of the federal estate tax upon large estates is so heavy that it amounts to a confiscatory capital levy. It is a tax deliberately contrived to destroy its most fruifful sources. Justification for the federal estate tax must be sought in its social significance. It is aimed directly at the destruction of large accumulations of property. Taken in conjunction with current federal spending policies and the federal incorne and gift taxes, the federal estate tax is part of a deliberate plan to rediscribute beth the capital and income of the nation. It is beyond the provinee of this paper to comment upon the wisdom of this particular brand of sxial philosophy. An active conscicusness of the motivating factors behind the federal fiscal poilicies is, however, the key to genuine insight into the problem of tax avoidance.

Under our constitutional organization the deciding battles over tax avopidance are . fought in the courts. Courts, curiously encugh, are simply men-and frequently men with definite social and political conviccions. By and large, lawyers and judges are apt to be advocates of the status quo. Pernaps the professional doctrine of stare decisis seeps through to color their social thinking. Until quite recently most of our federal judges were drawn from successful practicioners. Success in the practise of the law attracts wealthy clients and the character of a lawyer's convictions is apt to be shaped by the clients whose interests he is engaged to uphold. Ir is not any reflection upon the integrity of the federal judiciary to say that many judges were frankly hostile to the philosophy behind the modern federal tax system. 
The federal estate tax is peculiarly vulnerable to judicial sniping. A good many of the legal difficulties encountered by the tax arise from the fact that it cuts across the law of property. Most of the doctrines of the law of property crystallized in a period which took small account of death taxes. The legal conception of dower, for example, as an estate originating in the marital relation, rather than any act of inheritance, afforded needed protection to married women in an era when separate ownership of property by a married woman was impossible, and she badly needed some such form of protection. The strange conception of survivorship which visualizes the situation where one joint teriant or a tenant by the entirety dies, as a continuance of an existing title, rather than a transfer of any title, originated in connection with feudal tenure, where it was involed successively first as a device to uphold the feudal baron's prerogatives, and then to circumvent them. It would not add anything to continue the analysis along this line. The point is that the doctrines of the law of property are not legal immutables, but simply useful social devices invented to serve definite social needs. They can be made to mesh with a modern system of death taxation by intelligent and sympathetic adaptation. However, ther offer an opportunity for a court hostile to the federal estate tax to frustrate the tax. By inventing the doctrine that both the construction and constitutionality of the tax is to be determined by the presence of a testamentary transfer, and then erriphasizing the property rules which do not regard most of the living transactions taxed under the estate tax as testamentary, the courts managed to do considerable damage to the effectiveness of the estate tax in its formative period.

A stibstantial part of the ground lost under the earlier decisions has been regained recently under the influence of a more friendly judicial attitude toward the tax. By repudiating the testamentary transfer test of constitutionality and upholding as a legitimate incident of estate taxation any tax reasonably designed to prevent avoidance, ${ }^{g 1}$ the Court in a single bold stroke has cleared away most constitutional obstructions. A similar atritude seems to characterize the Court's present approach toward construction, recently manifested, for example, in the decision rejecting the distinction between a gift to vest upon the donor's predeceasing the dones, and a gift to divest upon the donee's predeceasing the donor.92 Although the Court has also indicated a recent willingness to go along with Congress and sustain the constitutionality of the retroactive features of the federal estate tax, unfortunately the technique followed so $\mathrm{far}$ in this connection has been a search for some sort of legalistic transfer afier the enactment of the tax, rather than any attempt to candidly appraise the genuine issues of fairness and policy. ${ }^{93}$ It may be that as the authority of the earlier cases is dissipated, the Court will take a more forthright stand on the problem of retroactivity.

\footnotetext{
"Helrering r. Caty Bant Farmers Trust Co; 296 U. S. 85 (3935); Helvering v. Bullard, 303 U. S. 297 (1938).

"3 Helvering s. Hallock, 60 Sup. Ct. 444 (1940).

-J Binney v. Long, supta note 90; U. S. 8. Jacobs, supre note 88.
} 
The change of heart which the Supreme Court has experienced toward the estate tax appears likely to be more than temporary. There has been a radical reconstruction in the personnel of the Court and the new justices are more or less committed to a political creed closely akin to the social philosophy underlying the tax. Most of the problems of tax avoidance under the federal estate tax will probably resolve themselves under friendly judicial handling and vigorous administration. There are, however, some situations where remedial action will probably have to be taken by the legislature."4

- For example, no satisfactory administrative technique has been developed for dealing with gifts in contemplation of death. See p. 312, supra. Congress might provide a conclusive presumption that gifts made within a certain period of death are in contemplation of death. Although this was held unconstitutional in Heiner v. Donnan, supre note 14, the authority of that decision has been seriously impaired, if not destroyed entirely, by the recent decisions, supra note 9r, adopting the "penumbra theory."

It would also appear that Congress should amend the insurance provisions to provide explicitly for a tax where the insured reserved no "legal incidents of ownership" at his death, see p. 325, supro; and tighten up the tax on powers of appointment by taxing the nop-exercise of a general power, and possibly exiending the tax to special powers. See pp. 322-323, supra. 